\title{
PENGARUH PENGGUNAAN FILLER DALAM PENGERINGAN TERHADAP PERUBAHAN KOMPONEN NUTISI DALAM PENYIMPANAN HASIL OLAHAN LIMBAH ORGANIK DAPUR DAN RESTORAN HOTEL
}

\author{
B. Sulistiyanto, Sri Sumarsih, C.I. Sutrisno, Nurwantoro, Istiyan P.M dan Anum D. \\ Jurusan Nutrisi Dan Makanan Ternak Fakultas Peternakan \\ -Universitas Diponegoro Semarang \\ Universilas Diponegoro Semarang
}

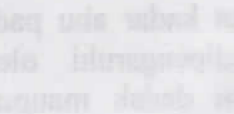
ara

Research of Effect filler addition in drying to nutrient component exchange in storage of processed organic wastes of kitchen and restaurant hotel's was done at the laboratory of Feed Technology, Department of Animal Nutrition and Feeding, Faculty of Animal Sciences UNDIP, Semarang. The research was aimed to study effect of filler addition in drying process of organic wastes of kitchen and restaurant hotel's to the quality of product observed from proximate component and total fungi exchange during storage. Experiment was conducted by factorial completely randomized design (CRD-factorial) $3 \times 2 \times 3$. Organic wastes of hotels class 1, 2 and 3 dried by adding filler 0 and $15 \%$ and were stored for 0,4 and 8 weeks. Component proximate i.e.: crude protein (CP), Crude Fat (CF), Crude Fiber (CF), Ash and Nitrogen Free extract (NFE) and total fungi are parameter observed. Data were statistically analyzed by Steel and Torrie (1981).

The result showed that interaction effects of rice brand addition and time of storing are significant to EE, CF and NFE $(P<0.05)$, but that effect to CP and Ash are not significant $(\mathrm{p}>0.05)$. Interaction between hotel class, filler and storing significantly affected total fungi in the processed product $(p<0.05)$.
\end{abstract}

Key words : filler, nutrition, waste of hotel

\section{PENDAHULUAN}

Meningkatnya aktivitas bisnis dan kesejahteraan masyarakat memerlukan penyediaan layanan jasa akomodasi sebagai pendukung mobilitas pelaku bisnis dan masyarakat awam yang sedang berwisata. Kualitas layanan akomodasi seperti hotel (berbagai kelas), losmen, wisma, cottage, villa bervariasi tergantung pada kelas dan jenisnya. Kota Semarang sebagai ibukota propinsi Jawa Tengah, menduduki posisi ke-empat setelah kabupaten Semarang, Banyumas dan Kota Surakarta dalam penyediaan sarana akomodasi untuk kepentingan bisnis maupun pariwisata. Namun demikian, kota Semarang menduduki posisi teratas dalam penyediaan akomodasi hotel berbintang, tingkat hunian dan kontribusinya terhadap pendapatan daerah dibanding kabupaten Semarang, Banyumas, kota Surakarta dan wilayah lainnya di propinsi Jawa Tengah (BPS, 2001). Layanan jasa akomodasi menurut Dirjen Pariwisata dibagi menjadi 2 (dua) kelompok besar, yaitu hotel berbintang dan usaha akomodasi lainnya. Selain. kemampuan dalam layanan fisik dan fasilitas pendukung yang lebih baik, ciri khusus yang membedakan hotel berbintang dengan usaha akomodasi lainnya adalah adanya restoran yang ada dibawah menejemen hotel tersebut (BPS, 2001). Sebagai akibat dari klasifikaksi tersebut, maka jenis dan jumlah limbah organik asal dapur dan restoran hotel dimungkinkan berbeda dengan jenis penginapan lainnya.

Limbah merupakan bekas atau sisa yang tak terpakai lagi sebagai hasil dari berbagai kegiatan manusia, dan biasanya dibuang ke tanah atau ke air. Limbah menjadi selalu dianggap sebagai ancaman serius bagi masyarakat, meskipun berbagai upaya telah dilakukan (Widayati dan Widalestari, 1996). Salah satunya adalah ancaman terhadap masalah kesehatan manusia (Sidharta, 1997). Limbah merupakan masalah, utamanya bagi masyarakat perkotaan, karena sistem penanganan yang kurang memandai dan jumlahnya yang terus meningkat. Sampah rumah tangga, limbah industri pengolahan makanan, limbah restoran dan hotel, merupakan limbah-limbah yang potensial dimanfaatkan sebagai pakan ternak (Widayati dan Widalestari, 1996 dan Jenie dan Rahayu, 2000).

Ternak pada hakekatnya adalah mesin biologis yang dapat merubah barang-barang yang tidak/kurang berguna menjadi produk/komoditas yang bernilai tinggi. Sejalan dengan meningkatnya kesejahteraan masyarakat, produk ternak yang berupa bahan makanan (susu, telur, daging), 
maupun produk lain (bulu, kulit, tulang serta tenaga) adalah komoditas yang sangat diperlukan manusia untuk menunjang keperluan hidup pokok (makan dan kesehatan) maupun keperluan kesenangan (estetika, dll). Namun demikian meningkatnya permintaan terhadap komoditas asal ternak tidak diikuti dengan kemampuan penyediaan pakan sebagai akibat dari terdesaknya penyediaan lahan untuk pengembangan dan budidaya tanaman pakan. Permasalahan pakan yang lain adalah inkontonuitas penyediaan pakan akibat musim. Upaya pemenuhan kebutuhan pakan mungkin dapat diatasi dengan intensifikasi pengembangan tanaman pakan serta pemanfaatan limbah pertanian. Kajian terhadap pemanfaatan limbah pertanian untuk ternak telah banyak dilakukan, lengkap dengan teknologi pengolahannya (Sutrisno dan Sulistiyanto, 1991), akan tetapi kajian terhadap limbah organik asal hotel belum banyak dilakukan.

Filler merupakan bahan yang digunakan untuk mengisi celah atau rongga dan mengisi volume. $\mathrm{Di}$ dalam proses pengeringan filler berguna untuk mempercepat proses pengeringan , sehingga mengurangi kerusakan nutrisi selama proses. Umumnya dipergunakan bahan sumber energi dan sekaligus berpotensi mengikat air (Hole, 1999 dan Kompiang dan Ilyas, 1983). Kualitas bahan selama penyimpanan sangat dipengaruhi oleh kualitas dan kondis bahan pada awal, khususnya hasil dari proses pendahuluan. Untuk itu penelitian ini dilakukan dengan harapan dapat mengetahui pengaruh penambahan filler dalam pengeringan terhadap daya simpan limbah organik lahan sekaligus dapat membantu menyelesaikan masalah lingkungan limbah hotel dengan mengkaji prospek pemanfaatannya pada ternak.

\section{MATERI DAN METODA}

Penelitian dilakukan di laboratorium Teknologi Makanan Ternak dan laboratorium Ilmu Makanan Ternak Jurusan Nutrisi dan Makanan Ternak Fakultas Peternakan UNDIP. Limbah diambil dari sample hotel dari kelas 1 (bintang 1 dan 2), kelas 2 (bintang-3) dan kelas 4(bintang 4-5) yang ada di Kota Semarang, selanjutnya limbah asal dapur dan restoran dikeringkan dengan penambahan dedak halus sebanyak $0,15 \% \mathrm{BK} / \mathrm{BK}$, dan dikeringkan dengan sinar matahari sampai kadar air 12-15\%. Analisis proksimat (AOAC, 1975). untuk mengevaluasi komponen nutrisi limbah hotel ulahan dan perhitungan total fungi dengan metocie cawan tuang (Fardiaz, 1989) dilakukan pada lama penyimpanan 0,4 dan 8 minggu. Data yang diperoleh dianalisis secara secara statistik untuk melihat pengaruh perlakuan terhadap perubahan komponen nutrisi dan jumlah total fungi (Steel dan Torrie, 1991)

\section{HASIL DAN PEMBAHASAN}

Kadar protein kasar dan kadar abu pada berbagai kelas hotel tidak dipengaruhi oleh interaksi perlakuan penambahan dedak maupun penyimpanan ( $>0.05)$, tetapi antar kelas hotel kadar protein kasar dan abu secara nyata berbeda $(\mathrm{p}<0.05)$. Kadar protein kasar pada kelas hotel 1, 2 dan 3 berturut-turut adalah 16,75; 13,90 dan $20,58 \%$. Hal ini dapat dipahami dari bahan penyusun limbah yang sebagian besar berupa sisasisa salad atau sayuran pada hotel kelas 2 (bintang 3), sehingga kandungan protein kasarnya pasilng rendah. Kadar abu pada kelas hotel 1,2 dan 3 adalah 7,$37 ; 10,81$ dan $10,38 \%$. Nampak bahwa komponen mineral lebih dipengaruhi oleh bahan asal yang kaya akan tulang dan duri pada hotel kelas 2 dan 3 (bintang 3, 4 dan 5) dari pada perlakuan penambahan dedak halus maupun penyimpanan.

Interaksi perlakuan penambahan dedak halus dan lama penyimpanan dan kelas hotel, secara nyata mempengaruhi kadar lemak kasar, serat kasar dan BETA-N $(\mathrm{p}<0.05)$. Pada penelitian ini nampak bahwa selain dipengaruhi oleh komponen asal penyusun limbah yang berbeda diantara kelas hotel, penambahan dedak halus dalam pengeringan dan lama penyimpanan terbukti berbengaruh terhadap penurunan kadar lemak. Penurunan ini dimungkinkan karena selama proses penyimpanan lemak mengalami proses kerusakan oksidatif. Proses sangat nyata pada limbah dari hotel kelas 3 (bintang 4 dan 5) yang memiliki kadar lemak $\pm 19,57 \%$ dan secara gradual menurun menjadi $16,09 \%$ dan $15,01 \%$ setelah penyimpanan 4 dan 8 minggu. Hal yang sama juga diperlihatkan limbah dari hotel kelas 1 (bintang 1 dan 2) kadar lemak menurun dari 6,$06 ; 5,97$ menjadi $4,68 \%$ pada lama penyimpanan 0,4 dan 8 minggu.

Kadar serat kasar dalam penelitian ini terbukti dipengarui oleh kelas hotel, penambahan dedak dan lama penyimpanan. Kelas hotel 2 memiliki kandungan serat kasar tertinggi dibanding dua kelas lainnya. Pengaruh penambahan dedak signifikan pada kandungan serat kasar hotel kelas 1 , hal ini dimungkinkan komponen penyusun limbah lebih banyak pada sisa nasi dan roti, sementara pada kelas 2 dan 3 lebih banyak pada sisa sayur dan buah. Kadar serat kasar menurun dengan lama penyimpanan. Hal ini dimungkinkan adanya 
aktivitas mikroorganisma yang mampu mendegradasi serat selama penyimpanan. Kemungkinan ini didukung hasil penelitian yang menunjukkan bahwa dalam limbah olahan masih terdapat fungi.

Kandungan BETA-N yang merupakan gambaran kasar dari komponen karbohidrat pada limbah dari hotel kelas I menürun dengan penambahan dedak halus, sedangkan pada kelas 2 dan 3 meningkat. Komponen karbohidrat ini menurun dengan lama penyimpanan. Hal ini dimungkinkan sebagian komponen karbohidrat dimanfaatkan oleh mikroorganisme untuk pertumbuhanya dan ini terlihat dari kecenderungan peningkatan kadar protein bahan selama penyimpanan.

Perbedaan komponen proksimat antar kelas hotel pada penelitian ini konsisten dengan penelitian Sulistiyanto et al., (2005) yang mencatat tidak ada perbedaan siginifikan antara hotel bintang 1 dan 2, serta antara hotel bintang 4 dan 5 . Perbedaan komponen limbah pada hotel bintang 1 dan 2 dengan bintang 3 dan hotel bintang 4 dan 5 tidak lepas dari menu yang disajikan dan pola serta gaya hidup konsumen.

Sulistyowati et al., (2005) mencatat bahwa kehilangan pangan (food losses) terjadi pada saat penyajian $(54,32 \%)$. Selanjutnya dikatakan bahwa sisa sajian ini selain disebabkan oleh komponen menu juga porsi sajian. Menu kaya karbohidrat serta sayur dan buah cenderung bersisa dibanding daging, karena tingkat kesukaan terhadap daging lebih tinggi dibanding sayur dan karbohidrat dan lemak.

Secara interaktif kelas hotel, penambahan dedak dan lama penyimpanan berpengaruh terhadap jumlah fungi dalam limbah olahan $(\mathrm{p}<0.05)$. Jumlah fungi yang tinggi pada hotel kelas 1 dan $3\left(1,5 \times 10^{6}\right.$ dan $1,8 \times 10^{6}$ sel per gram) meningkat dengan penambahan dedak halus menjadi $1,7 \times 10^{6}$ dan $2,4 \times 10^{6}$ sel per gram, dan selanjutnya menurun setelah penyimpanan 8 minggu menjadi $3,5 \times 10^{5}$ dan $3,1 \times 10^{4}$ sel per gram pada hotel kelas 1 dan 3 . Tingginya fungi pada limbah dari hotel kelas 3 relevan dengan kandungan lemaknya. Menurut Buckle et al.,(1987), bahan kaya mentega dan margarin merupakan media khamir jenis Candida lipolytica. Pada hotel kelas 2 (bintang 3) tidak menunjukkan perubahan yang signifikan jumlah fungi sebelum dan sesudah penyimpanan yaitu dari $1.1 \times 10^{5}$ pada awal menjadi $1.05 \times 10^{5}$ pada akhir minggu ke 8 . Peran bekatul sebagai filler (bahan pengikat air) mampu mengikat air bebas $\left(A_{W}\right)$, sehingga dapat menekan pertumbuhan fungi.

\section{KESIMPULAN}

Dapat disimpulkan bahwa penambahan dedak dalam proses pengeringan mampu mempertahankan kualitas hasil olahan dengan menekan perubahan kandungan protein, abu, lemak, serat kasar dan BETA-N selama penyimpanan, serta mampu menekan pertumbuhan fungi selama penyimpanan.

\section{DAFTAR PUSTAKA}

AOAC. 1975. Method of Analysis, Association of Official Analytical Chemist. Washington DC.

Biro Pusat Statistik. 2001. Direktori Hotel dan Jasa Akomodasi Lain Jawa Tengah 2000. BPS Jawa Tengah. Semarang.

Buckle, K.A., R.A. dwards, G.h. Flet dan M.Wooton. 1987. Ilmu Pangan. Universitas Indonesia Press. Jakarta. (Terjemahan: H.Purnomo dan Adiono)

Fardiaz, S. 1989. Analisi Mikrobiologi Pangan. Pusat Antar Universitas Pangan dan Gizi, Institut Pertanian Bogor. Bogor. (tidak diterbitkan)

Hole, D.1999.Understanding Ingridients Used in Ostric Feed. Bulletin Blue Mountain Feed No.51.

Jenie, B.S.L. dan Rahayu,P.W. 2000. Penanganan Limbah Industri Pangan. Penerbit Yayasan Kanisius. Yogyakarta

Kornpiang, I.P. dan S.Ilyas, 1983. Pembuatan silese ikan dengan penggunaan asam formiat. J. Penelitian Teknologi Hasil Perikanan 60:12-20.

Sidharta,S.K, Moersidik, S., Yusmilarso, S., Sulistyowati, Gusniani, I.S., Darmanto, Nasrullah. 1997. rekayasa Lingkungan. Universitas GunadarmaJakarta.

Steel, R.G.D dan J.H. Torrie. 1991. Prinsip dan Prosedur Statistika: Suatu Pendekatan Biometrik. Edisi ke-2. Penerbit PT 
Gramedia Pustaka Utama. Jakarta. (diterjemahkan oleh B. Sumantri)

Sulistiyanto, B., Sri Sumarsih, Sri Mukodinngsih, Ishaq danı Saechurochman. 2005. Studi Potensi Limbah Organik Dapur dan Restoran Hotel Untuk Pakan. Prosiding Seminar - Nasional Pengolahan Limbah:Prospek dan Tantangan Aplikasi. 13 Agustus 2005 Semarang . Hal: 12-15.

Sulistyawati, I., Indriani, P., dan Retnaningsih C. 2005. Kehilangan Bahan Pangan Pada Usah Jasa Boga Warung Tenda Masakan China di Semarang: Indikator In-Efisiensi Penggunaan Bahan Pangan. Prosiding Seminar Nasional Pengolahan Limbah : Prospek dan Tantangan Aplikasi. 13 Agustus 2005 Semarang. Hal: 118123
Sutrisno, C. I dan Sulistiyanto, B. 1991. Seri Informasi Pedesaan, Pedoman Praktis Penyediaan Pakan. Edisi I, Cetakan I, BP-UNDIP. Semarang.

Widayati, E. dan Widalestari, Y. 1996 . Limbah untuk Pakan Ternak. Penerbit Trubus Agrisarana. Surabaya. 